\title{
LYDIA JAEGER AND HERMAN DOOYEWEERD: DIALOGUES ON THE FOUNDATIONS OF CHRISTIAN SCHOLARSHIP
}

Author:

Renato Coletto ${ }^{1}$

\section{Affiliation:}

${ }^{1}$ School of Philosophy, North-West University, Potchefstroom Campus

\section{Correspondence to:}

Renato Coletto

Email:

Renato.coletto@nwu.ac.za

Dates:

Published: 01 Des. 2015

How to cite this article: Coletto, R., 2015, 'Lydia Jaeger and Herman Dooyeweerd: dialogues on the foundations of Christian scholarship'. KOERS - Bulletin for Christian Scholarship, 80(2). Available at: http:// dx.doi.org/10.19108/ KOERS.80.2.2223

\section{Copyright:}

(C) 2015. The Author(s). Published under the Creative Commons Atribution License.
This article introduces and discusses Lydia Jaeger's dialogue with and critical evaluation of a few aspects ofDooyeweerd's philosophy. From her critical realist position, Jaeger evaluates Dooyeweerd's rejection of the 'Logos-speculation' and his definitions of truth. As he deviates from the Christian epistemological tradition referring to the 'correspondence between thought and reality', Jaeger argues that he fails to connect subject and object sufficiently. I argue that in Dooyeweerd's ontology subject and object are thoroughly interwoven by the law-order. I also question Jaeger's critique that, in his epistemology, Dooyeweerd doesn't make sufficient use of biblical resources and is too inclined towards idealism. I suggest that Jaeger's contentions could be re-considered and that a more positive approach to reformational philosophy may open new avenues for her own research.

Key words: Christian philosophy and scholarship, Lydia Jaeger, Herman Dooyeweerd, Critical realism, Logos doctrine/speculation, Correspondence theory of truth, Reformational and Scholastic attitudes in philosophy

Hierdie artikel is ' $\mathrm{n}$ inleiding in, en bespreking van Lydia Jaeger se dialoog met, en kritiese evaluering van enkele aspekte van Dooyeweerd se filosofie. Jeager evalueer Dooyeweer se verwerping van die 'Logos-spekulasie' en sy definisies van waarheid vanuit haar krities-realistiese posisie. Omdat hy van die christelik epistemologiese tradisie afwyk, laasgenoemde verwysende na die 'korrespondensie tussen denke en realiteit', argumenteer Jaeger dat hy nie daarin slaag om subjek en objek genoegsaam met mekaar te verbind nie. Ek argumenteer dat Dooyeweerd se epistemologie subjek en objek deeglik met mekaar verweef deur middel van die wetsorde. Ek bespreek ook Jaeger se bewerings dat, in sy filosofie, Dooyeweerd nie genoegsaam gebruik maak van bybelse bronne nie en dat hy geneig is tot idealisme. Ek suggereer dat Jaeger se bewerings herbedink behoort te word en dat ' $n$ meer positiewe benadering tot Reformatoriese filosofie nuwe weë ook vir haar eie navorsing kan oopmaak.

Sleutelwoorde: Christelike filosofie, Lydia Jaeger, Herman Dooyeweerd, Kritiese realisme, Logosleer/-spekulasie, Korrespondensie waarheidsteorie, Reformatoriese en Skolastiese benaderings tot die filosofie 


\section{INTRODUCTION}

Lydia Jaeger is an Evangelical philosopher of science, with specialisations in theology, philosophy and physics. She is a prolific author who writes in several languages and has been associated with several universities in Germany, France and England. She is at present also Dean of the Biblical Institute of Nogent-sur-Marne, near Paris. As I regard myself too as an Evangelical and I lecture in philosophy of science, I was immediately interested in her work. We are both wellacquainted with the neo-Calvinist ${ }^{1}$ tradition of Kuyper, Vollenhoven, Dooyeweerd, Van Til (in South Africa also Stoker, in France also Lecerf). While I lean more on the Dooyeweerdian side, I had the impression that she leans more on the Van Tilian side. But then she recently clarified that, as far as she is concerned, she 'takes inspiration from both' these giants of the Kuyperian tradition. ${ }^{2}$

Given this background, when I came across an essay ${ }^{3}$ of hers dedicated to Dooyeweerd's philosophy, I was somehow surprised to find that it harbours a rather radical critique of Dooyeweerd's position. In that text, in fact, she advances several objections against Dooyeweerd's epistemology and ontology. These objections are rather fundamental and seem to leave little hope for further dialogue. They seem to parallel Blocher's trenchant verdict on several aspects of Dooyeweerd's epistemology: 'I have had to conclude that he is wrong' (Blocher, 2010:227). Nevertheless, Jaeger begins her essay by saying that her critique is to be understood as a sign of interest in Dooyeweerd's philosophy and concludes by pointing out several areas of agreement between herself and Dooyeweerd (2012:309-310). I am therefore encouraged to think that my present 'ecumenical' exercise will not be perceived as irrelevant.

In this article, I will reply to Jaeger's essay by trying to argue that her contentions against the Dutch-reformed philosopher should be re-considered. On the one hand, in my opinion, Dooyeweerd's philosophy is closer than she may think to several themes, concerns and results that she pursues and develops in her own writings. On the other hand I will also deliver a few critiques of Jaeger's position, with the purpose of suggesting that a reformational alternative might fit better with $\mathrm{a} /$ her Christian approach. In the next section, however, the first step is to introduce her epistemological convictions and her critiques of Dooyeweerd's philosophy.

$1 \quad$ In this article I will use the term 'neo-Calvinist' as including all scholars and circles in the Kuyperian tradition, and therefore as a synonym of 'Kuyperian'. I will reserve the adjective 'reformational' to refer to the specific school of Dooyeweerd and Vollenhoven.

The text is in French and all translations appearing in this article are mine. In English, the title of Jaeger's (2012:299-310) essay is: 'Herman Dooyeweerd, the Logos-speculation and the truth'. The essay is part of a collection, edited by Alain Nisus, by the title The love of wisdom: [essays in] homage to Henri Blocher.

\section{Jaeger's theses and contentions}

Jaeger's epistemological position is rooted in the Christian tradition, in what she calls the 'traditional Christian theory of knowledge' (Jaeger, 2012:303). Her conception is based on the idea of creation and on the doctrine of the Logos, the second person of the Trinity. According to Jaeger, this doctrine excludes all nominalist and idealist views and invites to a (moderate) form of realism. Jaeger's epistemology, therefore, is a realist one, yet she does not opt for naive realism. Her conception, quite popular in Christian circles, can be defined as critical realism. From that point of view, the object of knowledge is not isolated from the knowing subject: the two are 'tuned' to each other.

The Logos doctrine allows overcoming a traditional problem of classical realism, the problem of connecting the subject and the object. It is not always clear, in fact, that or how the two should be related to each other, in other words why/how the object should be open to human knowledge. On this junction the doctrine of the Logos plays an essential role. The human subject, created in God's image, can recognize in the object a creature that is known by the Logos. As she writes: 'the correspondence between (...) knowing person and world to be known is granted by the double presence of the Logos' (Ibid: 303). The Logos is 'present' to both of them.

The knowing subject too has a double connection to the Logos: true knowledge is given not only by the correspondence between thought and object but also between thought and Thought (human and divine thought - Ibid: 308-309). There are no 'brute facts' in the cosmos, they are always pre-known and pre-interpreted by the Creator. Human thinking is veridical when it corresponds to divine thought. As Van Til used to say, it is a matter of 'thinking God's thoughts after Him'.

The Logos is the ordering principle of the universe, from which all things derive. The Bible, says Jaeger, affirms this truth in the Prologue of the Gospel of John. Several Greek philosophers recognised the Logos as the rational order of the cosmos. Christians should not shy away from this recognition: 'all truth is God's truth', even when it is proclaimed by pagans (Ibid: 307). Conversely, when John wrote about the Logos (in the Prologue to his Gospel), he knew that the idea was already present in the Greek world and that it had connotations that were not exactly biblical. Nevertheless, his Prologue creates a bridge between the Old Testament and Greek culture (Ibid: 305).

These are Jaeger's theses briefly summarized. Her critiques against Dooyeweerd's philosophy are the following.

1. Dooyeweerd rejects what he calls the 'Logos-speculation' on the basis that there are very unsatisfactory versions of the doctrine of the Logos (e.g. in Clement, Origen, Tertullian). Yet the cost of this rejection is that he cannot properly connect the subject to the object. In Dooyeweerd's philosophy the Logos is substituted by the (naive experience of the) self (Ibid: 303). The previous allegation is stated from a different angle: 
2. Dooyeweerd's conception of the truth is not based on the classical correspondence between thought and reality, or thought and facts (adequatio rei et intellectus). As a consequence, his epistemology does not provide a sufficiently direct contact between 'the human spirit and the world' (Ibid: 308). One should also consider two other critiques.

3. Dooyeweerd's epistemology does not stem from and is not the result of an intense interaction with the biblical text (Ibid: 307-308).

4. His position results in a certain dose of idealism: he is too inclined towards Kant and Husserl (Ibid: 310).

Jaeger's reflections place her in an ideal dialogue with Dooyeweerd, a dialogue on the foundations of Christian philosophy with crucial implications for the nature of Christian scholarship. In the following section we are going to analyse the first allegation.

\section{Dooyeweerd's rejection of the Logos-speculation}

Jaeger is supported in her (moderate realist) position by several reformed giants of the past, not only Kuyper but also Bavink and Woltjer. It might be objected, however, that Jaeger finds herself also in the company of Thomas Aquinas and other Scholastic authors. In addition, the reformed theologian Geerhardus Vos (1980:478-484) expressed clear reservations concerning critical realism and, even more interesting, Van Til himself articulated a few perplexities concerning the use of the Logos doctrine in Bavink's epistemology (Van Til, 1974:94-95). To complicate the picture even further, one might add that both Dooyeweerd and Vollenhoven did initially accept a form of critical realism similar to Kuyper's and equally informed by 'trinitarian' themes (cf. Tol, 2011:192-199). Only at a later stage they found it un-satisfactory and decided to opt for an alternative (i.e. reformational) solution.

But apart from the supporters and detractors of critical realism and the Logos doctrine, Jaeger recognizes that Dooyeweerd's critique of the 'Logos speculation' is profound. After examining the Greek conceptions of the Logos (e.g. Philo and Plotinus Dooyeweerd, 2012:68-74) he takes into account several Christian versions of the doctrine (Ibid: 74-80) and he shows that they all contain important flaws (Ibid: $82 \mathrm{ff}$.). Dooyeweerd's concerns are not only theological, they proceed on philosophical grounds. The major problem that he mentions is that 'the Logos-theory logicizes the creation order' (in other words absolutizes the rational modality - Ibid: $83 \mathrm{ff}$.).

Jaeger is prepared to admit (with Van Til, 1971:441) that the preNicean versions of the Logos-doctrine are not satisfactory from a theological point of view. In fact, they reduce the Logos to a kind of 'inferior' deity. But she sounds slightly surprised by the fact that 'Dooyeweerd's critique is extended to Augustine as well' (Jaeger, 2012:304, 306). Interestingly, at this junction Jaeger does not respond to Dooyeweerd's criticism of Augustine's (post-Nicean) Logos-theory, she just assumes that an acceptable version of the doctrine must exist. Unfortunately, she does not clearly indicate which (whose) version of the doctrine might be acceptable, and I think this weakens her argumentation to an extent.

The only clue she provides on this issue is that, in a proper version of the Logos-doctrine, the correspondence between thought and fact should be integrated by the correspondence between thought and Thought (human and divine thought, Ibid: 308-309). But how does the latter make the "contact" between the knower and the object of knowledge more direct? After all, the thought-Thought correspondence seems to be a move away from the object. In this context Jaeger (Ibid: 309, fn. 32) quotes Auguste Lecerf, but in her own paraphrase of his position Lecerf refers to the necessity of understanding the "structure" (the law) of/for created reality, not divine thought. Lecerf seems rather to support a reformational understanding of these issues (which will be discussed below). Finally, she does not respond to the crucial issue of the logicization of the created order (I will return on this issue below).

Perhaps feeling that the best defence is attack, Jaeger proceeds to argue that, in his philosophy, Dooyeweerd consciously replaces the Logos with the naive experience of the self. She writes that the naive experience of the supra-temporal self plays in Dooyeweerd the role traditionally attributed to the Logos in the classical Christian theory of knowledge' (Jaeger, 2012:303). The idea was not immediately clear to me, but I think she means the following. While in critical realism the Logos connects subject and object, in Dooyeweerd's philosophy a similar connection is envisaged in his conception of naive (or pre-scientific) experience. There the subject is placed in direct contact with objects, events and processes: in this sense naive experience plays the role of the Logos in connecting object and subject. This direct contact is acceptable to Jaeger, with the only regret that the Logos is replaced by the self.

When it comes to theoretical thought, the situation is definitely worse: there Dooyeweerd introduces an antithesis, an opposition between subject and object. True, the antithesis is followed by a synthesis, but the theoretical attitude of thought is characterised by an antithesis. In addition, the self is again the 'hidden player' making possible (after a theoretical antithesis is intentionally set up) the synthesis between the logical aspect of the act of thought and the non-logical aspects of the object of scientific investigation (Dooyeweerd, 1984, 1:45). Does not Dooyeweerd then, fail to see the direct correspondence between subject (or thought) and object? Furthermore, does he not anchor his epistemology to the subject, thus creating a rather subject-ivist, or idealist type of approach, reminiscent of Kant and Husserl? This is how I understand Jaeger's arguments on this topic.

\section{The theoretical attitude of thought}

Concerning the theoretical attitude of thought (in which an 'antithesis' is established) I would say that the comparison proposed by Jaeger is not completely linear. While in the Logos approach the connection to be explained is the correspondence of thought and facts, in Dooyeweerd this is not the case. 
When Dooyeweerd speaks of antithesis, it is not an antithesis between subject and object but 'only regarding the logical aspect of our act of thought as opposite to the non-logical aspects of reality' (Dooyeweerd, 1948:31). ${ }^{4}$ His problem is the functioning of theoretical thought. The antithesis concerns the laborious process of theorizing, the effort which must be put in place to obtain theoretical knowledge. Subjects and objects may be thoroughly interwoven by the Logos, yet this does not mean that we have instant understanding of concrete reality and its laws. I think Dooyeweerd wanted to highlight the fatigue of scientific investigation, the sense of 'opposition' or resistance experienced in the process of analysis.

Now, Dooyeweerd's account of theoretical thought can sound more or less convincing, plausible or accurate. But it does not crucially depend on the idea of opposition. For example, Strauss has re-phrased and simplified the whole theory by focusing on the idea of abstraction. (Modal) abstraction is the 'heart' of theoretical thought and it includes both analysis and synthesis (distinction and identification) as its two 'legs'. Synthesis is then not the counterpart of opposition but of distinction (i.e. analysis -Strauss, 2009:13 ff., 361-368). In this re-construction of Dooyeweerd's theory ${ }^{5}$ the theoretical 'opposition' between aspects is no longer necessary. Could this open new avenues of dialogue between Kuyperian scholars and circles?

While keeping this hope, we need to return to my previous remark that Jaeger has not responded to a fundamental objection raised by Dooyeweerd (2012:83 ff.), that the Logosspeculation implies a logic-ization of the created order. In fact, as the demiourgos (in Plato) shapes the un-created matter he follows a rational plan and has a rational purpose. The rational (logical) modality, therefore, is both the foundation and the goal of his creative activity (Ibid: 82). In Dooyeweerd's language this means that the logical or rational aspect is absolutised, while the non-logical modalities are reduced to (sub-) modalities of the logical aspect. The implications of this idea were imported from Greek into Christian thinking. Even though in Christianity matter loses its divine attributes, creation still occurs according to God's thoughts, its order is a rational order and the correspondence between thought and fact is logical. In this construction the risk, for the object, is to become not only open to logical analysis but logically qualified (i.e. fundamentally logical). The risk is also that the logical (and mathematical?) laws may be regarded as un-created (therefore as divine).

Dooyeweerd $(1984,1: 52-55)$ argues that, in his transcendental critique, Kant committed precisely the fallacy of identifying the "transcendental logical cogito" (logical aspect) with the self that directs the cogito. As a result, the logical aspect of the act of thought is mistakenly assumed to be the agent performing the act of theoretical thought. Consequently, the true character of theoretical thought and its true starting point have remained hidden, and the autonomy of theoretical reason has been accepted as a truism.

Strauss' 'reconstruction' uses materials provided by Dooyeweerd himself, as the latter does sometimes characterize theoretical thought in terms of abstraction (cf. 1984, 2:472), though he may not necessarily abandon the idea of 'opposition'.
Does this logicization affect Jaeger's discourse as well? For example, is the fact that she is prepared to regard as synonyms terms like thoughts/words, linguistic/propositional and thought/discourse a first symptom of a logicization of the created order? She writes:

How should we compare facts and their interpretation (in thoughts or in words), given the fact that they are two very different categories? How can we establish a relationship between a linguistic (or propositional) and the factual element which is supposed to correspond to it? (...) The antinomy between fact and thought (or discourse) has no ground to exist (Jaeger, 2012:309).

What is the reason why she tends to associate words and thoughts so closely? Why should words, in the following step, be included in the pole of 'thought' (the counterpart of 'facts')? Are words fundamentally thoughts? Is the Word of the Prologue of John, also to be regarded as essentially rational and as the provider of the rational order of the cosmos?

\section{Connecting subject and object: Dooyeweerd}

Whatever answer one may give to the previous questions, we have not yet clarified whether Dooyeweerd failed or not in connecting the human subject of knowledge to the objects, thus falling into idealism. In the previous section I have argued that Dooyeweerd's 'doctrine' of theoretical thought does not necessarily imply a separation between knower and knowable. But this concerns only theoretical thought, it does not exclude that, in other areas or in other ways, Dooyeweerd creates excessive distance between subject and object. It is therefore necessary to analyse other parts of his philosophy.

To do this, I suggest that his understanding of the subjectobject relation is a strategic locus to begin with; more strategic, I would say, than his definitions of the term 'truth' (on which I will return below). Basically, in Dooyeweerd's ontology, what connect the subject to the object are the modal (universal) laws. Both subjects and objects are subjected to the law(s). In this sense I would say that Dooyeweerd's epistemology is clarified by his ontology.

According to Dooyeweerd all entities function in all modal aspects, either as subjects or objects (to use Clouser's language: passively or actively - Clouser, 2010:5). Cats function as subjects (i.e. actively) in the first six modalities: they have four paws (numeric aspect), when they are born they have a small size (spatial), then they learn to move around (kinematic), they get stronger (physical) and eventually they grow older (biotic) and their sight is less sharp at night (sensory). In the subsequent aspects cats function 'passively', as objects: they do not form concepts, but they can be analysed conceptually. They do not give names to their kittens but they get names. They do not sue anybody but they may belong to someone, thus functioning in the juridical modality. The modalities in which entities function as objects (passively) are always present, but they might not always be actualised. Actualisation occurs through a subject. For example, the photographs of the lunar environment provided by satellites allow our appreciation of the beauty of 
those landscapes. The potential for aesthetic admiration was always there, but now it is disclosed to subjects and by subjects. In other words the mentioned object-functions were latent but have been made patent (disclosed) by a subject.

At this point it is necessary to avoid the (wrong) impression that, in Dooyeweerd's philosophy, the subject-object relation presents itself only in the logical or rational modal aspect. The subject-object relation presents itself in each and every modal aspect, and therefore is not only about knowledge. For example in the sensory aspect we can perceive an object or feel an emotion. In the physical aspect a subject can hit an object (for example kick a ball). In the ethical aspect a subject can love an object, for example one's country or friends. ${ }^{6}$ This is made possible by the fact that objects and subjects function in the same modalities and are subjected to the same laws. Basically, then, we can say that objects and subjects are connected through the modalities in which they function. Troost (2012:96) observes that this is not an external or superficial type of link between entities that have little or nothing in common. On the contrary, it is an internal link, as entities are qualified by specific modalities. ${ }^{7}$ The world does not only contain subjects and objects (as philosophers of science often assume), but is an ordered cosmos, in which objects and subjects are subjected to the law-for creation, the structural modal order.

From this point of view, the very distinction between subject and object should be handled with care. Objects are never only objects: they are also subjects, at least in some dimensions (aspects) of life (cf. Hart's remarkable analysis 1984:221 ff.). Not only: in some cases subjects too can be objects. Human beings can be logically analysed, for example, individually or as groups, from a biotic, psychic, historical or social point of view. Finally, both subjects and objects are subject-ed to laws.

I find the following remark by Strauss particularly illuminating on the inclinations of reformational philosophy. He writes: "it is an effect of the "subject-centredness" of modern philosophy (sometimes plainly designated as its subjectivism) that everything different from the human being is turned into an "object"' (Strauss, 2009:346). With the last few remarks I have moved a bit away from Dooyeweerd, to have a look at some

Another wrong impression could emerge in relation to the logical modality, namely that, according to Dooyeweerd, the subject-object relation is present only in naive experience. Such impression could be generated by the fact that Dooyeweerd says that we know an 'object' only in naive thought, while in theoretical thinking we know a 'Gegenstand'. It should be pointed out, however, that in theoretical thinking (i.e. when abstracting modalities) we do not lose sight of the object completely. The theoretical attitude of thought does not replace the naive attitude but, we might say, it is added to it. On this point Dooyeweerd might not have clarified his position sufficiently.

n his commentary on Dooyeweerd's philosophy, Troost writes: 'what we call the external world is so integrally interwoven with our human subjectivity, that the so-called subject-object split can be little more than a faulty mental construction, an erroneous fantasy (...)' (Troost, 2012:96). other authors in the reformational tradition. I would like to continue this 'stroll' in the next section.

\section{Connecting subject and object: the reformational tradition}

The relevance of the law is a theme which is particularly prominent in Jaeger's writings (cf. Jaeger, 2008, 2010a, 2010b). It might be that, on closer examination, she could find in reformational philosophy a closer ally than she assumes at present. $^{8}$ In this tradition, admittedly, scientific truth or objectivity is not simply the result of a correspondence between 'thought and facts'. However, Jaeger also gives alternative definitions of truth: as correspondence between a) 'thought and world' to be known (Ibid: 303) or between b) 'thought and reality' (2012:307). This raises a question: to what precisely should our theories correspond to, within the world or reality? The relativist, for example, tends to create a correspondence between theory and (the conceptions or definitions of) the human subject of knowledge. The subject too is part of 'reality' and part of 'the world'. From a reformational point of view, Stafleu suggests that scientific truth or objectivity should be re-defined as 'correspondence to the law' (Stafleu, 1987:241). In his opinion this idea of 'law-conformity' is required by the 'reformed conception of the law' (Ibid: 241). One may agree or not with this specific proposal, but it is still a 'correspondencetheory' of knowledge and it is certainly not an idealist project, creating a gulf between knower and knowable.

According to Hart (1984:82-83), who blends in his ontology the positions of Dooyeweerd's and Vollenhoven, the laws, the 'nomic conditions' are nothing else than the universals, that occupied such a central place in the discussions of Medieval philosophy. From an ontological point of view, this is equivalent to granting existence to the universals, which is quite far from any nominalist (idealist) conception. In this sense, reformational ontology could even be called 'realist'. However, in my opinion, it constitutes an original position, an alternative inspired by the biblical revelation and rooted in the recognition of the law (cf. Hart, 1984:19 ff.). This 'stroll' through the reformational tradition should leave no doubts concerning the fact that it is not an idealist tradition.

Coming back to Dooyeweerd, there is one more difference between his and Jaeger's attempts at connecting subject and object. For Jaeger the biblical worldview suggests that the two must be (are always) 'tuned' to each other. From there she might argue that this is more suitable to promote the scientific enterprise, that it is more in line with the Christian tradition and so forth. Yet she does not show philosophically that and how this tuning or correspondence occurs, or is possible.

8 I have in mind for example reformational scholars like Van Riessen and Stafleu. According to Stafleu the reformed (and reformational) conception of the law is the one that prevailed since the Copernican 'revolution', even though the secular versions of it do not recognise the Origin of laws (Stafleu, 1987:239-240). Van Riessen observes how the recent reluctance to recognise the law, in several academic disciplines, is often due, on the religious level, to a refusal to recognise a law-Giver (Van Riessen, 1992:55). 
Dooyeweerd's argumentation, by contrast, is not only a faithposition but a philosophical explanation of the connection. Jaeger's weakness on this point is the same characterizing Kuyper's position. He too wanted to avoid idealism and he too appealed to the Logos to explain the correspondence between subject and object. It was a faith-inspired choice. On this point Klapwijk recently observes that while the appeal to the Logosdoctrine can help understanding Kuyper's intentions, it does not prove the point that the Father of neo-Calvinism wanted to argue (Klapwijk, 2013:25). From my side, I have to agree: a faithcommitment is not yet a philosophical argumentation.

\section{Dooyeweerd's definitions of 'truth'}

The critiques presented up to this point constitute only one leg of Jaeger's argumentations, aiming at demonstrating the insufficient connection of subject and object in Dooyeweerd's philosophy. The other leg is constituted by her discussion of Dooyeweerd's conception of the truth. However, the previous exploration of the subject-object relation presented by Dooyeweerd is relevant in this case too, and I believe it can again shed light on the discussion.

I will omit a description of the 'perspective structure of truth', in relation to the 'horizons of human experience', as it is already well presented by Geertsema (2005:87-88, 92 ff.). I will rather focus on Jaeger's (2012:308) impression that Dooyeweerd's definitions of 'truth' are quite complex and such complexities cannot deliver the simple adequatio of thought and fact. Let us briefly examine a first definition of truth.

According to its transcendental a priori dimension truth is: the accordance between the subjective a-priori knowledge enclosed by the temporal horizon, as expressed in a-priori judgements, and the a priori structural laws of human experience within this temporal horizon. The latter is open (as to its law- and subject-sides) to the light of the transcendent Truth in Christ (Dooyeweerd, 1984, 2:573).

The above definition includes 'both the pre-theoretical and theoretical dimensions of transcendental truth' (Ibid: 573). A more specific definition of theoretical truth reads as follows.

The correspondence of the subjective a-priori meaningsynthesis as to its intentional meaning with the modal structure of the 'Gegenstand' of theoretical thought. The modal 'Gegenstand' is included in its all-sided coherence within the temporal horizon. This coherence exists both in its foundational and transcendental direction of time and is dependent on the transcendent fullness of the meaning of truth (Ibid: 572).

One may notice that in both definitions truth is regarded as a correspondence to modal dimensions (see the 'a priori structural laws' in the first quotation above and the 'the modal structure of the Gegenstand' in the second). In other words, the theme of 'correspondence to the law' emerges again and if the previous discussion is taken into account, it will become clear that no antithesis or disconnection between 'subject and object' is in view.
Dooyeweerd's epistemology is still one of correspondence. No one could insist that there are "undeniable states of affairs" as he does and fail to have a correspondence view. But he disagrees for example with Aquinas' formulation and makes it a prime example of what he rejects. Thomas holds that truth is an agreement between "thought and being" and takes belief to be "intellectual assent". Dooyeweerd (1984, 2:566) disagrees because Aquinas' solution relates knowledge and truth only to the intellect, to the logical aspect of knowing. For him knowledge and belief take place in the heart not just in the intellect. In that way they involve the whole person in all his or her aspects (Dooyeweerd, 1984, 2:571)

Jaeger (2012:307, fn. 26) does report that she noticed Van Woudenberg's (2005:116-117) observation that Dooyeweerd's epistemology is still one of 'correspondence'. Yet she did not pursue that direction to find out where it may lead. She quickly concluded that Dooyeweerd's correspondence still does not 'create a direct contact between the human spirit and the world to know' (Ibid: 308). The simple fact that Dooyeweerd does not fully conform to the 'conception traditionelle' (or even to a specific 'formula') is considered sufficient to declass his proposals. The fact that Dooyeweerd dares criticizing Bavink's critical realism seems to be regarded as a proof that he does not create a direct contact between the knower and the world (2012:308, fn. 29). On this point, one has the impression that Jaeger is a bit too hasty in delivering her verdict. ${ }^{9}$

In the next section we need to proceed to discuss her third allegation, concerning the relationship between Dooyeweerd's philosophy and Scripture.

\section{Philosophy and Scripture}

Although recognising that Dooyeweerd wants to erect his epistemology on biblical grounds, Jaeger (2012:307, fn. 24) observes that he does not engage in a deep interaction with the biblical text. Admittedly, Dooyeweerd usually refers to broad biblical themes, rather than to specific verses. In his opinion Christian scholarship cannot be derived from a few texts and fragments, but is shaped especially by the biblical ground motif of creation, fall and redemption. ${ }^{10}$ Ample use of biblical texts is sometimes even regarded with suspicion by Dooyeweerd. He once wrote about both Augustinian and Protestant

\footnotetext{
9 Haste betrays Jaeger also in her footnote 29 (p. 308). In fact, in the passage of the New critique that she quotes there (i.e. Dooyeweerd 1984, 1:560, fn.2) Dooyeweerd's criticism is not directed (as she claims) to Herman Bavink (the reformed theologian) but to the German philosopher of nature Bernard Bavink.
}

\footnotetext{
This is a somewhat 'classical' assessment of Dooyeweerd's use of Scripture. Yet, should one start counting the instances when he quotes or refers to specific biblical texts, one might be quite surprised by the abundance of scriptural references. In this regard I would mention in particular his Roots of Western culture (1979). For Dooyeweerd however biblical quotations do not have the function of constituting or proving philosophical arguments but to show an agreement between the (philosophical or scientific) 'building' and its (religious) 'foundations' (Dooyeweerd, 2012:50).
} 
Scholastics that 'the more alien the foundation of their philosophy were to the Christian religion, the more copious (...) became their appeals to the biblical texts' (2012:50).

Jaeger's conception is also derived from the Scriptures, both from particular texts and from general themes. As far as themes are concerned, her epistemology is based on the theme of Creation, in particular on 'the distinction between creation and Creator' ${ }^{11}$ (Jaeger, 2012:306). And then of course she relies on the biblical texts dealing with the Logos. Now, a philosopher might not be the best candidate for exegetical discussions. Fortunately, in this case I can rely on a (Van Tilian) theologian (i.e. Oliphint, 2010:375-388) who objects to the use of the Logosdoctrine in support of realist epistemology, and does so by way of biblical exegesis.

What type of knowledge does the Logos provide, according to the Prologue of the Gospel of John? Surely, it is a type of knowledge that all men share, knowledge that 'enlightens all men' (v. 9). Surely, it is knowledge that the Logos supplies since the creation of the world. According to Oliphint, however, it is not knowledge of 'objects' or facts. It is rather the knowledge of God, knowledge of the Logos himself (Oliphint, 2010:387). This is in line with the verses in Romans 1, teaching that God is known by all human beings, although this type of knowledge is then, so to speak, repressed or removed. Obviously, these findings constitute a non-marginal blow to the use of the Logosdoctrine in support of (critical) realism.

Yet is not the Logos also the rational order of the world? This was the understanding of the Greek readers of the Gospel of John, says Jaeger (2012:305), and the apostle would not have ignored this background understanding. He knew that by using the word Logos he would have induced his readers to think of the cosmic rationality, and he did not write anything to prevent or counteract that understanding. Should we not conclude that in the doctrine of the Logos the biblical meaning and the 'natural' understanding of its Greek readers contribute to a richer picture? Oliphint is rather clear-cut on this point:

The true meaning of the term, however, is not to be gleamed from a synthesis of its historical use and its biblical use. God infallibly inspires the use and its true meaning in the writing of his own word (Oliphint, 2010:377, fn. 57).

The Logos, therefore, says Oliphint (2010:388-389) by supplying the knowledge of God, supplies what Bavink calls the principium essendi of epistemology, the source, foundation or

11 In this regard, I find it difficult to follow some of Jaeger's remarks concerning Dooyeweerd's understanding of this biblical theme. Firstly she (2012:307) denounces an inclination 'to conceive the distinction between Creator and creature in an antithetical mode'. Nevertheless, her further explanation of this idea in footnote 24 (Ibid: 307 ) speaks of Dooyeweerd's insufficient distinction between Creator and (human) creature. Dooyeweerd's distinction would be compromised by his conception of the supra-temporal heart (a divinisation of the self?). Nevertheless, in her footnote 25 (Ibid: 307) Jaeger refers to Acts 28, 17 ('for we are also His offspring') to defend 'the continuity between God and humanity'. cause of knowledge. This principium is necessary, says Oliphint, but not sufficient to legitimize or to erect a realist epistemology. All this brings Oliphint (Ibid:39o) to the conclusion, which I gladly support, that the Christian scholar should stick to the principle of Sola Scriptura. Not in the sense that the Scripture is the only reference point for epistemology, but in the sense that the Scripture should have prominence over all other reference points shedding light on the matter. From this point of view, therefore, the Christian scholar, working in epistemology, should remain faithful primarily to the Scriptures, ${ }^{12}$ not to realism or to any other 'conception traditionelle'.

This whole discussion is of course linked to the attitudes of accommodation and reformation in philosophy. Dooyeweerd (2012:46 ff., 51 ff.) distinguishes them sharply and regards Scholastic philosophy too as the result of a synthesis between Christian and pagan elements. Yet Jaeger too, from her position, regards Dooyeweerd's philosophy as compromising with Humanist philosophy, in particular with the idealism of Kant and Husserl (Jaeger, 2012:310).

\section{Dooyeweerd, Kant and Husserl}

The fact that there are 'analogies' between the philosophies of Dooyeweerd, Kant and Husserl is not a secret. Already in a text dating back to 1962, for example, Knudsen (2009:327-329, original 1962), recognized and listed several areas of 'analogy'. Dooyeweerd himself recognises the 'thousand ties' $(1984,1: 118)$ linking his philosophy to Kant in particular and to (contemporary) philosophy in general. And yet, right after this recognition, Dooyeweerd also claims that in its fundamental stance, reformational philosophy sets itself against Kantianism and secular philosophy in general. Knudsen too, after recognizing the analogies, proceeds to describing the substantial differences between the Dooyeweerdian and phenomenological approaches (Knudsen, 2009:329 ff.).

I should perhaps supply a brief example based on the definitions of truth that were quoted above. There we find the term 'a priori', which is typical of the philosophies of both Kant and Husserl. And yet, once one starts analysing Dooyeweerd's use of this term, one discovers that a priori refers to what is given in creation. The a priori has a subject-side and a law-side. 'The subjective insight, expressing itself in judgments' can be true or false. It is however dependent on structural laws (Dooyeweerd, 1984, 2:548). The basic difference with Kant and

12 I am not always comfortable with the way Jaeger and Blocher deal with biblical verses or themes in connection with philosophical issues. A few years back Blocher (1986:6) managed to derive from the biblical distinction between God and creation, the idea that human beings reflect in their constitution a duality (body and soul) which is already present in 'the entire reality'. In the concluding paragraph of her essay, Jaeger (2012:310) quotes Acts 17, 28 ('in Him we have our life, movement and being'). If this is intended to counteract Dooyeweerd's well-known argument that we should distinguish between God as 'being' and creation as 'meaning', I think the attempt is rather biblicistic. In any case, Dooyeweerd does not say that creatures have no 'being', but that 'meaning is the creaturely mode of being' (see $1984,1: 4)$ 
Husserl is that for Dooyeweerd the subject is not the a priori foundation of knowledge (Geertsema, 2005:95).

Once again, it would be helpful to place Dooyeweerd's philosophy in the broader context of reformational philosophy. It would then appear quite clearly that, since its beginnings, this movement has pointed out that the very roots of phenomenology and Kantianism are incompatible with an integral Christian approach. One might think for example of the text Creation, revelation and philosophy by Mekkes (2010, orig. 1961) or The rise and development of the phenomenological movement by Van der Hoeven (1964). ${ }^{13}$ Is it plausible to imagine that Dooyeweerd's attitude (sympathetic towards Kantianism and phenomenology - according to Jaeger) resulted in such sharp oppositions in the works of so many reformational authors? Would this not have raised at least some perplexities within this school? How come that Dooyeweerd himself $(1984,2: 487)$ defined phenomenology as "the most dangerous adversary" among the schools of humanist philosophy?

It would be equally helpful to know in which area or in which sense, according to Jaeger, Dooyeweerd's compromise with 'idealism' ${ }^{\prime 14}$ took place. Unfortunately, she does not clarify precisely how or where such a questionable synthesis occurred. In the absence of this information, perhaps my approach should be more 'presuppositional', in the sense of focusing on the assumptions of Jaeger's discourse. In other words, one should ask questions like: is it fair for Jaeger, to accuse Dooyeweerd of compromise, after effectuating her own synthesis with (one may even say her 'full immersion' in) the Scholastic tradition?

Is it fair to accuse Dooyeweerd of accommodation after showing that accommodation is legitimised by the Bible itself? Is not her understanding of the Logos the result of a synthesis between the biblical and the Greek understanding of this idea? Furthermore, she approves Blocher's thesis that the epistle to the Hebrews 'shows some affinities with the synthesis that Philo created between the Torah and Platonism' (Jaeger, 2012:305). In the same vein, she takes Paul's reference to the pagan poet Aratos (Acts 17,28 ) to prove that 'the biblical authors are not afraid of corrupting the purity of their teaching by resorting to the categories utilised by Greek philosophers' (Jaeger, 2012:307).

$13 \quad$ Further examples from subsequent decades are constituted by Bongho Son (1972), Strauss (1982), Kuk-won Shin (1994).

After such declarations, what complaints could one address to Dooyeweerd, concerning syntheses or compromises?

One might consider that, probably, from Jaeger's point of view, joining an established Christian tradition is a much more legitimate choice than joining secular traditions (like those initiated by Kant and Husserl). Yet this provides an opportunity to say that the Scholastic tradition in philosophy is deeply rooted in the pagan tradition. In certain respects, Scholasticism is as pagan as Humanism! Humanism too can be regarded as a re-elaboration of Christian and biblical themes. Humanism is not simply paganism: it passed through centuries of (synthesis-) Christianity, and it could be regarded as a by-product of Christianity itself. At least, this was Klapwijk's thesis, reflecting Hegel's famous dictum, according to which Western culture has been shaped in the shadow of Christianity (Klapwijk, 1987:105 ff.). ${ }^{15}$ But this is only half of an integral (may I say: an Evangelical) point of view: it needs to be supplemented by the recognition that both Scholasticism and Humanism, although influenced by Christianity to an extent, are immensely indebted to pre-Christian thought.

Of course this doesn't mean that everything in those traditions must simply be rejected or that Christians should say the opposite of what they say. Yet my impression is that Jaeger has not paid sufficient attention to Dooyeweerd when he points out the threat that Scholastic philosophy poses to integral Christian scholarship. Admittedly, in Jaeger's essay one does find arguments showing that she recognises and is aware of these problems. Unfortunately, those arguments are accompanied by others, pointing towards a different direction.

\section{CONCLUDING REMARKS}

The dialogue between Jaeger and Dooyeweerd is a precious conversation on the very foundations of Christian science and scholarship. It is also part of a long standing dialogue between the different branches of the Kuyperian tradition. In some cases the distance between these circles might remain substantial, yet the attempts at dialogue and mutual understanding are necessary, if we want to support truly Christian scholarship. This exercise requires self-examination as well.

In some reformed circles, there is an established tradition of placing Dooyeweerd's philosophy on a shelf after briefly paying lip-service to it. Usually, what is accepted from his philosophy is something that is already available from Kuyper, Van Til or some other theologian. From that shelf, reformational philosophy can be "exhibited" to interested visitors and outsiders, but for the rest it is hardly mentioned or used anymore. On the basis (or rather: with the pretext) of this or that alleged inadequacy, this philosophy stemming from the Reformation is basically ignored. Remarkably, a whole host of para-Christian, or overtly secular approaches are preferred to it (cf. Blocher, 2010:227; Frame, 1987:146, 318).

\footnotetext{
15 'I would even defend the thesis', writes Klapwijk, 'that practically the whole of modern humanistic philosophy derives from a transformation of the Christian inheritance' (Klapwijk, 1987:105-106).
} 
This article recommends a re-evaluation of several themes of Dooyeweerd's philosophy as a Reformed and Evangelical philosophy. It is my impression that Jaeger's evaluation of Dooyeweerd's philosophy could be more positive and several of her critiques should be re-considered. Admittedly, this exercise would imply some self-critique as well. But it would lead to a (re-)discovery of many and valuable resources, not only in Dooyeweerd's philosophy but in the reformational tradition as well.

\section{BIBLIOGRAPHY}

Blocher, H., 1986, 'De l'âme et de l'ésprit', Ichthus 17(6), 3-11.

Blocher, H., 2010, 'Afterword: open letter to Lydia Jaeger', in L. Jaeger, Einstein, Polanyi and the laws of nature, p. 217-229, Templeton Press, West Conshohocken PA.

Clouser, R.A., 2010, ' Brief Sketch of the Philosophy of Herman Dooyeweerd', Axiomathes 20(1), 3-17.

Dooyeweerd, H., 1948, Transcendental problems of philosophical thought, Eerdmans Publishing Company, Grand Rapids, Mi.

Dooyeweerd, H., 1959, 'Cinq conferences', La revue réformée, 10(3), 3-76.

Dooyeweerd, H., 1979, Roots of western culture: pagan, secular and Christian options, Wedge Publishing Foundation, Toronto.

Dooyeweerd, H., 1984, A new critique of theoretical thought, Paideia Press, Jordan Station.

Dooyeweerd, H., 2012, Reformation and scholasticism in philosophy, Volume 2: Greek and Medieval philosophy, Paideia Press, Grand Rapids, Mi.

Frame, J.M., 1987, The doctrine of the knowledge of God: a theology of lordship, Presbyterian and Reformed Publ. Company, Phillipsburg, N.J.

Geertsema, H.G., 2005, 'Dooyeweerd on knowledge and truth', in J.H. Kok (ed.), Ways of knowing in concert, p. 85-100, Dordt College Press, Sioux Centre, Ia.

Hart, H., 1984, Understanding our world: an integral ontology, University Press of America, Lanham, Md.

Jaeger, L., 2008, 'The idea of law in science and religion', Science and Christian Belief 20(2), 133-146.

Jaeger, L., 2010a, Einstein, Polanyi and the laws of nature, Templeton Press, West Conshohocken, PA.

Jaeger, L., 2010b, 'The contingency of the laws of nature in science and theology', Foundations of Physics 40(9-10), 1611-1624. DOI 10.1007/s10701-010-9470-y

Jaeger, L., 2012, 'Herman Dooyeweerd, la spéculation sur le Logos et la vérité', in A. Nisus (ed.), L'amour de la sagesse: hommage à Henri Blocher, p. 299-310, Edifac/ Excelsis, Vaux-sur-Seine/Charols.

Klapwijk, J., 1987, 'Reformational philosophy on the boundary between the past and the future', Philosophia Reformata 52(2), 101-134.

Klapwijk, J., 2013, 'Abraham Kuyper on science, theology and university', Philosophia Reformata 78(1), 18-46.

Knudsen, D.R., 2009, Roots and branches: the quest for meaning and truth in modern thought, edited by Donald Knudsen with an introduction by William Edgar, Paideia Press, Grand Rapids, Mi.

Mekkes, J.P.A., 2010, Creation, Revelation, and Philosophy, Translated by Chris Van Haeften, Dordt College Press, Sioux Centre, Ia.

Oliphint, S.K., 2010, 'Bavink's realism, the logos principle and sola Scriptura', Westminster Theological Journal 72(2), 359-390.

Shin, K.W., 1994, A hermeneutic utopia: H.G. Gadamer's philosophy of culture, Toronto Tuppence Press, Toronto.

Son, B.H., 1972, Science and person: a study on the idea of philosophy as rigorous science in Kant and Husserl, Van Gorcum, Assen.

Strauss, D.F.M., 1982, 'The place and meaning of Kant's Critique of pure reason (1781) in the legacy of Western philosophy', South African Journal of Philosophy 1(2), 132-147. 
Strauss, D.F.M., 2006, 'The best known but least understood part of Dooyeweerd's philosophy', Tydskrif vir christelike wetenskap/Journal for Christian Scholarship 42(1-2), 61-80.

Strauss, D.F.M., 2009, Philosophy: discipline of the disciplines, Paideia Reformational Project, Grand Rapids, Mi.

Stafleu, M.D., 1987, Theories at work: on the structure and functioning of theories in science, in particular during the Copernican revolution, University Press of America, Lanham, Md.

Tol, A., 2011, 'Reformational philosophy in the making', Philosophia Reformata 76(2), 187-215.

Troost, A., 2012, What is reformational philosophy? Paideia Press, Grand Rapids, $\mathrm{Mi}$.

Van der Hoeven, J., 1964, The rise and development of the phenomenological movement, Association for Reformed Scientific Studies, Hamilton, Ontario.

Van Riessen, H., 1992, 'Science in the light of the relation between thinking and believing', Tydskrif vir Christelike Wetenskap 28(1), 27-95.

Van Til, C., 1971, 'Response by C. Van Til [to Arthur F. Holmes]', in E.R. Geehan (ed.), Jerusalem and Athens: critical discussions on the philosophy and apologetics of Cornelius Van Til, p. 438-444, Presbyterian and Reformed Publ. Company, Nutley, N.J.

Van Til, C., 1974, An introduction to systematic theology, Presbyterian and Reformed Publ. Company, Phillipsburg, N.J.

Van Woudenberg, R., 2005, 'Two very different analyses of knowledge', in J.H. Kok (ed.), Ways of knowing in concert, p. 101-122, Dordt College Press, Sioux Centre, la.

Vos, G., 1980, Redemptive history and biblical interpretation: the shorter writings of Geerhardus Vos, Presbyterian and Reformed Publ. Company, Phillipsburg, N.J. 